Historic, Archive Document

Do not assume content reflects current scientific knowledge, policies, or practices. 
. 


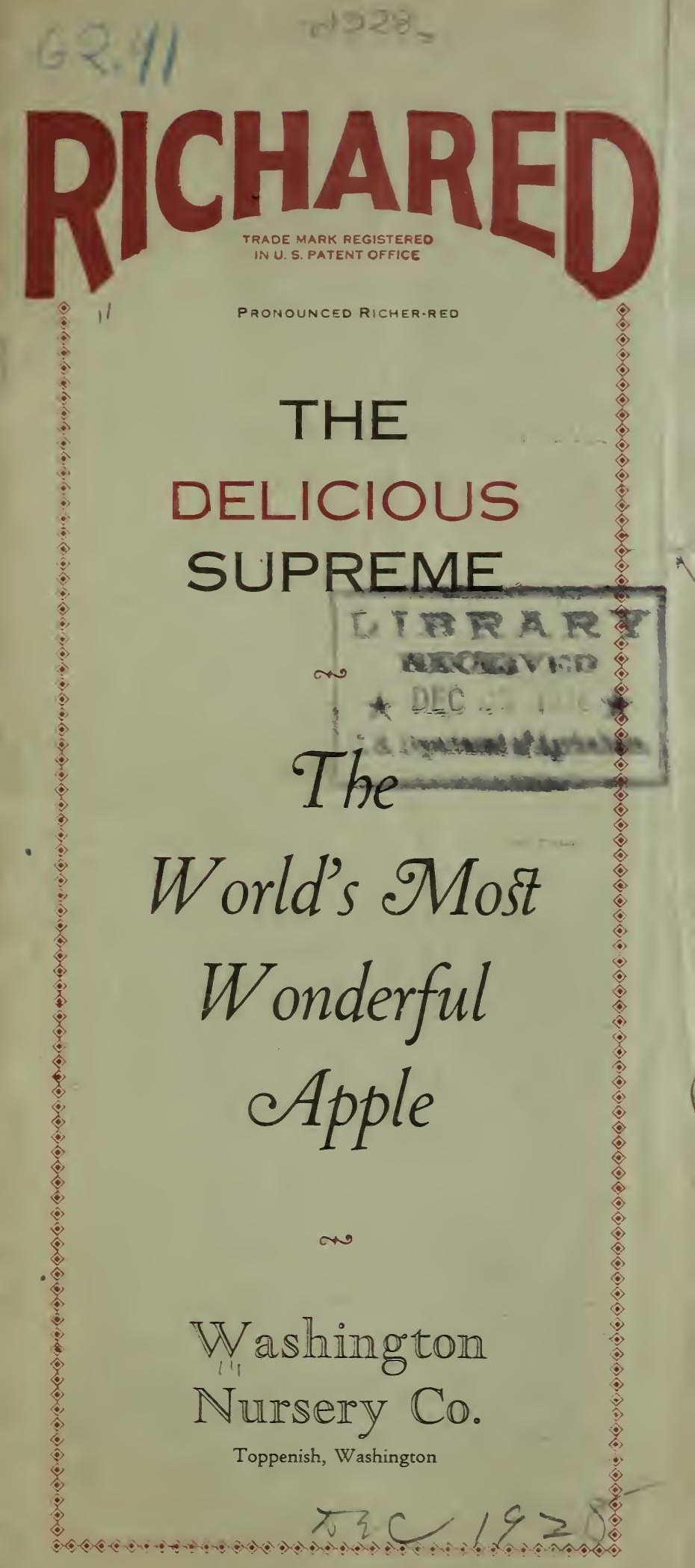




\section{Announcement}

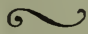

\section{Washington Nursery Co.}

Toppenish, Washington

is pleased to announce that it has made arrangements with the Columbia \& Okanogan Nursery Company of Wenatchee, Washington, to grow and distribute trees of the "RICHARED" DELICIOUS.

The history and description of this wonderful apple, together with the opinion and endorsements of prominent horticulturists, apple growers and fruit shipping organizations are given in the following pages of this booklet, the subject matter of which was originally collected and published by the Columbia \& Okanogan Nursery Company. We have obtained that Company's permission to reprint it.

The Wenatchee Valley of Washington is the largest producer of Delicious apples in the world. Total shipments of this popular apple from that district for the years of 1926 and 1927 amounted to more than 6,000 car loads. Since the recent discovery of the "RICHARED" DELICIOUS, plantings of the common Delicious in that district have been discontinued in favor of this super Delicious.

We are happy to say that through our connection with the discoverers and original propagators of this beautiful blood red apple, we are able to grow and offer the trees for sale. 


\title{
The Story of
}

\section{"Richared" Delicious}

\author{
(Trade Mark Reg. in U.S. Patent Ofjice)
}

\section{(Pronounced "Richer-red")}

The most amazing and startling apple discovery ever made.

A "Super" Delicious. An apple with all the good qualities of common Delicious: Same size-same shape-same flavor-same texture, and same ripening period.

\section{But}

The "Richared" Delicious colors two to three weeks earlier and COLORS SOLID RED (without trace or sign of stripe) even into the stem and blossom ends! It can be picked "hard ripe" with full color. It has excellent storage qualities and is the most beautiful, glorious apple ever seen.

Read the story on the following pages.

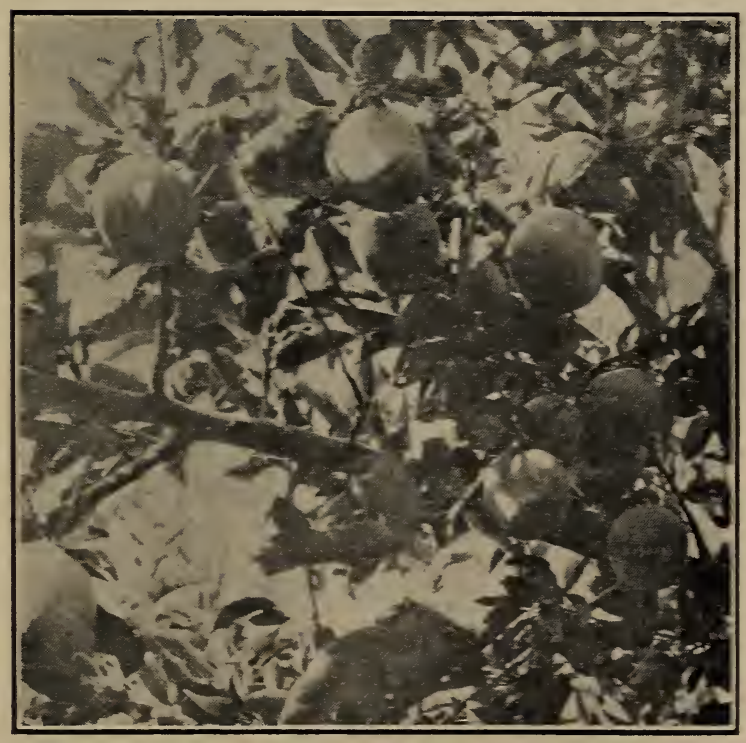

Limb on Third Generation "Richared" Delicious Tree Loaded With Biood Red Apples 


\title{
Planted Ten Acres This Year, Will Plant Twenty Acres Next Year
}

\section{WELLS \& WADE FRUIT COMPANY}

\author{
Wenatchee Valley Fruits
}

Wenatchee, Wash., October 28, 1927.

The writer has observed with keen interest your development of the "Richared" Delicious apple. Five years ago my attention was called to the Red Delicious tree in the Richardson Orchard, and I have made regular trips each season to inspect the fruit produced by this particular tree and to learn, first-hand, how much and what quality of fruit it yielded, and whether or not trees propagated from its buds would reproduce the same red apples.

I was also interested to find out if these apples retained the Delicious flavor of this variety and as to the keeping quality of the apples in storage.

The results of my investigations were such that I planted ten acres of the "Richared" this past spring (98\% of these trees show a most satisfactory season's growth) and am now clearing the ground for setting another twenty acres, which will be set to this new variety of Delicious.

I believe, and have no hesitancy in saying to you, that in your "Richared" Delicious you have propagated a tree which has the vigor, productiveness, high quality and keeping qualities that will make it one of the most profitable varieties grown.

Yours very truly,

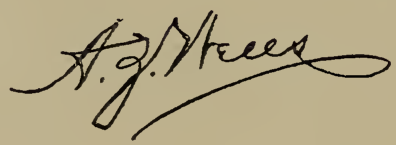

Mr. Wells is senior partner of the well known Wells \& Wade Fruit Company. Their brand, the "Twin W," is known wherever Extra Fancy boxed apples are sold.

Mr. Wells also owns and operates an orchard of about one hundred acres. 


\section{The Story of "RICHARED" Delicious}

(Trade Mark Registered in U. S. Patent Office)

\section{THE DELICIOUS SUPREME}

In the spring of 1910, Mr. G. T. Richardson planted near Monitor, Washington (a small village in the heart of the wonderful Wenatchee Valley) an orchard consisting of four hundred and twenty-five Delicious apple trees. When the orchard came into bearing. Mr. Lewis Richardson, the present owner, noticed that all the apples on one tree were a much deeper red in color than any of those on the adjoining trees. He did not at once pay much attention to the matter, but after the same thing happened the third time, he decided it was very unusual and showed some of the apples to Mr. Gossman. of the Columbia \& Okanogan Nursery Co., of Wenatchee. Washington.

\section{Nursery Company Amazed}

The company immediately investigated what, to them, seemed to be an extremely unusual occurrence, and one which might have very far reaching influences in the fruit world at large. They were surprised and astonished to find this tree loaded with apples that were dark solid red color, without any trace of stripes, while in shape, size, etc., they resembled the common Delicious on adjoining trees which were still uncolored, or only partially colored.

Upon further examination these apples were found to possess the identical flavor, texture, and ripening period of the Delicious apples on adjoining irees, the sole difference being that thev colored at least two weeks earlier and without trace of stripes. 


\section{American Fruit Growers Orchard Manager Makes Large Plant of "Richared"}

Wenatchee, Wash., Oct. 24, 1927.

Last spring I decided to set out an orchard of my own, and my observations over a period of years led me to believe that I wanted a large portion of my own orchard planted to Delicious, as it has been a consistent money getter for the grower in this district. After a good deal of deliberation, I decided that your "Richared" Delicious was the apple I wanted on account of solid, blood red, early coloring, early picking, less liability of loss from drop, large percentage of Extra Fancy, as this colors so much more than the common Delicious, coloring even in the shade and dense foliage, together with better keeping qualities. All these qualities convinced me that this was the profitable apple for me to plant, and I did plant about one thousand of them last spring. They were good trees and have made very satisfactory growth.

Yours very truly,

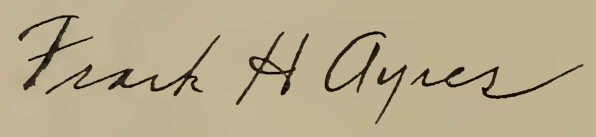

Mr. Ayers is orchard manager of the 276-acre Birchmont Orchards, belonging to the American Fruit Growers, and has been in charge of this immense orchard for the last seven years. On account of his practical experience as an orchard grower, orchardists in this district have a great deal of respect for his judgment regarding orchard practices.

In addition to Mr. Ayers' personal plant, the American Fruit Growers also planted many "Richared" Delicious trees this past year. 


\section{The Story of "RICHARED" Delicious}

(Continued from Page 5)

\section{Discovery Means Millions of Dollars to Fruit Industry}

The nursery company saw at once that here was something that was worth millions of dollars to the apple industry of the world, providing trees could be propagated and grown which would produce fruit identical with that of the parent tree. They accordingly entered into negotiations with $\mathrm{Mr}$. Lewis Richardson, the son of the original owner, and who is now the owner of the orchard, and secured the exclusive propagating rights from this tree. They grafted several surrounding trees and also budded a number of young nursery trees from the original tree.

\section{First Reproduction in 1925}

In the fall of 1925 they were rewarded by seeing one of the grafted trees bear fruit identical with that of the parent tree, coloring up blood red, without stripes, even in the shaded portions of the tree, and fully two weeks earlier than apples on other Delicious trees in the same orchard. Immediately all available propagating wood was used to produce nursery trees, to supply an enormous demand which was sure to come.

\section{Young Trees Reproduce Fruit True to Type}

In the fall of 1926 some of the young trees which were set out previously also bore fruit, and as was the case with the older grafted trees, they reproduced true to type of the parent tree. By this time many leading orchardists of the Wenatchee Valley had heard of this wonderful tree, had seen the fruit, and were quick to realize the importance of a Delicious that would color early, that could be picked with full color, while hard ripe, weeks before ordinary Delicious, and the company was literally swamped with orders for trees which would bear this marvelous fruit.

(Continued on Page 9) 


\section{Statement of Owner of Original}

\section{Tree}

Wenatchee, Wash., Nov. 15, 1926.

For the information of any who may be interested, I will say that the tree bearing the solid red Delicious apples, which you have named "Richared," was planted in 1910 by my father and was one of about 400 Delicious trees which he planted at that time in one block. This tree, while looking in every way exactly like all the other Delicious trees, has always borne apples that color up solid red without any trace or indication of stripe. They color up at least two weeks earlier than the Delicious on adjoining trees and they are always ready to pick at least two weeks before the others.

Another thing, practically every apple on the tree colors up with full color so that I get nearly $100 \%$ Extra Fancy color on these apples, while some seasons my common Delicious have run as high as $40 \% \mathrm{C}$ grade. If all my trees had been Richared instead of common Delicious, I would have received about $\$ 2500$ more money for my 1925 crop of 5000 boxes from $5 \frac{1}{2}$ acres.

Several years ago the C. \& O. Nursery Co.'s attention was called to this tree and budded some young trees with buds taken from it, and this year they came into bearing and produced apples exactly like those on parent tree; solid red, no stripes and colored up two weeks earlier than my common Delicious. I also set some grafts in old trees and these produced fruit this season identical with the Richared in every respect.

Hundreds of people have seen these young trees and the grafted trees and have seen the solid red apples which they produce. I think nearly every prominent horticulturist in this valley as well as nearly all prominent apple shippers have seen the original tree in bearing and also the apples on the young trees and grafted trees. Without exception they were amazed at the deep red color of these apples in comparison with Delicious on adjoining trees which were still green.

Yours truly,

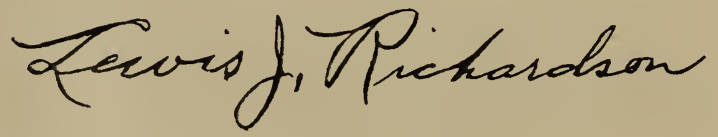


The Story of "RICHARED" Delicious

(Continued from Page 7)

\section{How "Richared" Got Its Name}

As a compliment to Mr. Richardson, the Nursery Company named the fruit "Richared," the first syllables being taken from the word Richardson, as well as being descriptive of the characteristic color, a "RICHER" $R E D$, and the name "Richared" is so pronouncedRicher-red.

This is the story of the origin of this, the world's greatest apple, the "Richared" Delicious.

We ask you to read the succeeding pages which we are sure will convince any orchardist, horticulturist, dealer, or anyone else interested in the development of better apples, that our claims are founded on facts.

\section{What the "Richared" Delicious Means to the Apple Industry of the World}

In the preceding pages you have been told that the Richared Delicious colors two weeks earlier than the common Delicious, that it has an absence of stripes, being in fact solid blood red, the most beautiful, glorious looking apple in existence; that it colors solid red even in the shade of the trees, which common Delicious does not do.

In order to expel any doubt that may be in your mind as to what this really means, we ask that you read the following pages.

\section{Early Color and Its Advantages}

We wish to call your attention to the importance of early color in the Delicious apple, and to emphasize it particularly.

It has long been known that the average orchardist is prone to leave Delicious on the trees too long. He is looking for more color (which will place his apples in the Extra Fancy grade) but the quality of the fruit is impaired thereby.

As a result, Delicious apples are often left on trees until they become mealy and reach the market in an over-ripe condition. If the orchardist picks them when they should be picked they grade as Fancy or C Grades, which usually means fifty cents to a dollar less per box.

(Continued on Page 11) 


\section{Far Superior to Common Delicious}

I first observed the original Richared Delicious tree in Mr. Richardson's orchard in 1923 and when I saw it bearing dark red apples which were full colored even in the shaded parts of the tree, while apples on other Delicious trees all around this were still uncolored, I decided here was something that was far superior to the common Delicious. Mr. Richardson consented to my taking a few scions (with approval of your company) and I now have about 400 young apple trees top worked to Richared Delicious. This year (1927) a few of my grafted trees had apples on, and they are identical with those on parent tree-full blood red color without stripes.

I am enthusiastic about the Richared Delicious and believe it to be the best apple yet found.

\section{(Signed) F. A. SCHELL.}

Mr. Schell has one of the finest orchards in the Wenatchee Valley near Cashmere, Wash. He has made a success of orcharding.

$$
\text { A "Royal" Gift }
$$

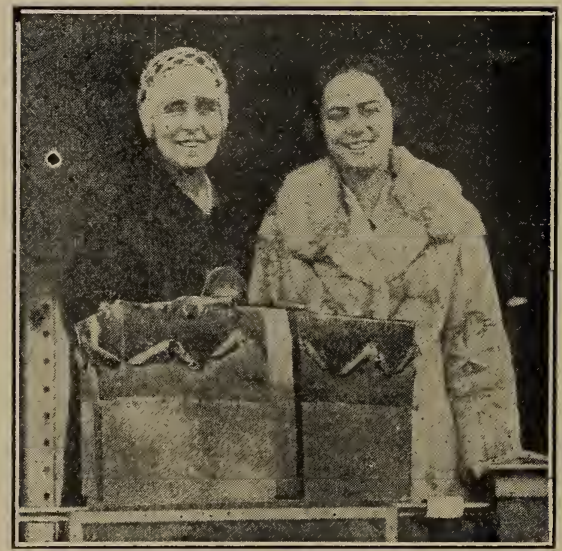

Queen Marie and Princess Ileana of Roumania receiving a box of "Richared" Delicious from the Wenatchee Chamber of Commerce, presented at Wenatchee, November, 1926, while the Roumanian party were touring the United States. 


\section{The Story of " RICHARED" Delicious}

(Continued from Page 9)

\section{No Mealy Apples}

With "Richared" Delicious we have entirely overcome this objectionable feature. They can be picked while HARD RIPE, and yet have full color, which will put them in Extra Fancy grade; and they will bring the top market price. They can be put on the market as "Extra Fancy" two weeks before common Delicious. This usually means an average of fifty cents a box more moner. (These figures are based on Government Market Reports for the last five seasons. This year. 192 7 , the early market Delicious in New York was about seventyfive cents more per box than two weeks later.)

Early color also means better keeping qualities. By picking the apples while "hard ripe" they can be put in cold storage and kept until late spring. so that if the early market happens to be "weak" the orchardist can take advantage of cold storage, feeling assured that his "Richared" Delicious will be in excellent condition for a later market possibiy at an advanced price. (March and April prices on good quality appies usually are considerably higher than fall prices.)

\section{Early Picking and Why It is Best}

As emphasized in the discussion of early coloring, so also early picking is essential not only from the standpoint of market value, but, as is especially the case with Delicious. from the standpoint of quality of fruit. No one likes mealy apples, and this class of fruit has done more to ruin the apple market than any other one factor. Apples arrive dead ripe and must be sold at once or they are a total loss. As a result they are put on the market at any price to move them and the grower stands a loss instead of receiving a profit. We quote from a bulletin issued by the Northwest Fruit Exchange. Wenatchee. Wash.. and dated Septembe: 16, 1926. 


\section{LAW OFFICES \\ McAULAY \& FREECE \\ YAKIMA, WASH.}

During the summer of 1926 I concluded to plant an orchard of Delicious apples. Having heard of the Richared, I decided to investigate. Accordingly I made a special trip to Wenatchee in August, 1926, and visited the Richardson Orchard where I saw the original Richared Delicious tree and also younger trees propagated from the original tree, both bearing apples.

These Richared Delicious apples were solid red in color while those on surrounding trees were still green or slightly streaked with red. So far as I could determine then, they were in every other respect identical with the common Delicious having the same remarkable texture and flavor.

I have raised and marketed many carloads of apples and it has been my experience in the marketing of apples that the early market is usually the best. From what I saw on the trip I concluded that the Richared Delicious apples could easily be put on the market at least two weeks in advance of the common Delicious grown in the same locality. I therefore decided that in planting additional apple trees I would plant the Richared instead of the common Delicious. I therefore ordered from you three hundred fifty Richared Delicious, and have planted them in Yakima County. They were nice thrifty stock and have made a very satisfactory growth.

I might say further that on this same trip in August, I was present at a cold storage plant in Wenatchee when you were preparing some of the previous year's apples for an exhibition at the Okanogan fair and you took out of cold storage some of the Richared Delicious apples grown during 1925, and if I remember correctly there was only one decayed apple in the box which I saw opened. All of the others were as firm and crisp, apparently, as the day they were packed. I also ate some apples from this box and they had lost none of their rich, delicious flavor.

I expect to make an additional planting of Richared Delicious this coming spring.

Very truly yours,

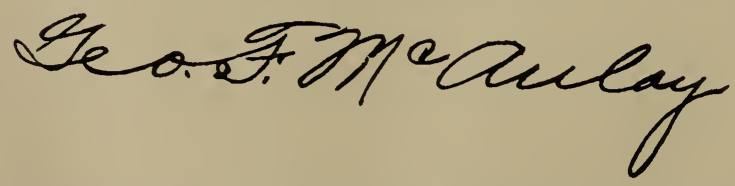

Since the above was written, Mr. McAulay has placed his order for another large lot of "Richared" Delicious trees. 


\section{The Story of "RICHARED" Delicious}

(Continued from Page 11)

\section{Overripe Fruits and Ruined}

\section{Markets}

"Warning! Under date of September 2 we sent you a bulletin urging the early color picking of Jonathan and Delicious apples and attempted to point out some very important advantages to be derived from this practice. Growers of this district have been slow to start picking operations. In districts where color picking has not been followed we yesterday found . . . in some of these orchards only the top and outside apples colored, but these should be picked when properly matured and not left to become over ripe and soft while waiting fo: color on the inside of the tree . . Over-ripe fruit has done ten times the damage to our markets that immature fruit has done. Shipment of over-ripe fruit results in losses, rejections, claims, and generally unsatisfactory market condition."

With the Richared Delicious you can avoid the experience warned against in the above bulletin. There is another advantage of early picking and an important one as many a grower can testify from past "costly" experience. Any grower of apples knows what "Windfall" apples are and the cause thereof. As already stated, many growers leave their Delicious too long in order to get better color. As a result they are ripe, and if a wind comes along there is a heavy drop and a heavy loss. Many a grower has seen a season when his entire profits were wiped out by windfalls. We quote again from a Northwestern Fruit Exchange Bulletin, September 16, 1926:

"Delicious in the earlier districts were ripe ten days ago. Delicious in West Wenatchee have been falling badly for a week, and those who have not removed the top and outside apples before now have suffered or are suffering a considerable loss. A wind at this time would make a world of $\$ 2.00$ per box Delicious into $\$ 2.00$ per ton culls. We urge that no time be lost in picking." 


\title{
The Greatest Apple Discovery Ever Made
}

Farly
Color
1
Double
Red
,
Koeper
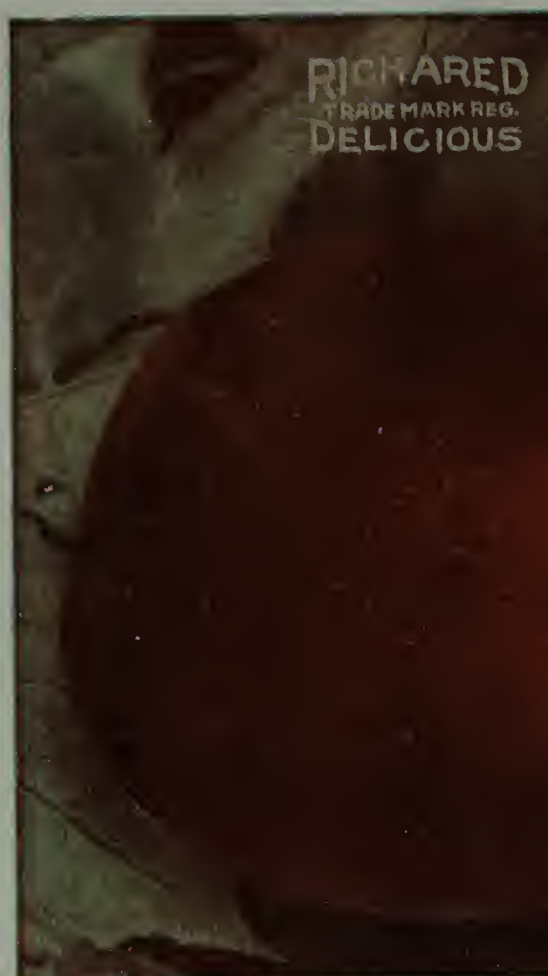

$d$
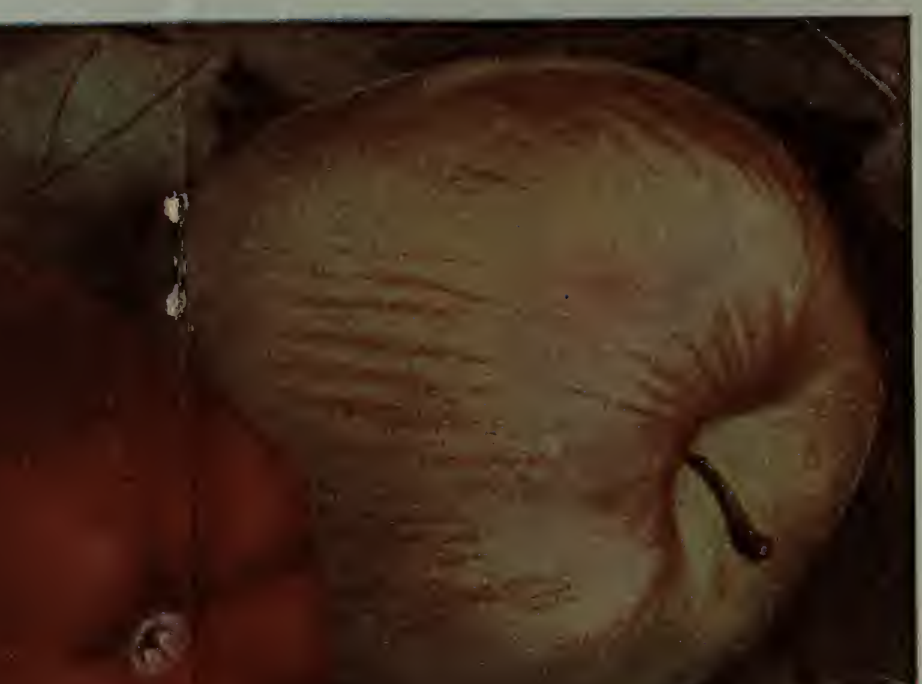

Pick

Early

1

Windfalls

All Red "August Color" Still Green

REPRODUCED FROM FRUIT AND PHOTOGRAPH

This is not a picture of two mature Delicious Apples, but shows the contrast between a "RICHARED" and an ordinary Delicious, both picked same day, same orchard, from adjoining trees in late August.

While "RICHARED" Delicious colors solid red no stripes) weeks earlier than common (striped) Delicious, and can be picked while "hard ripe," it is iden cal with the common Delicious in shape, size, texture,
flavor and ripening period.

Do not confuse this "Wonder" apple with other so-called Red Delicious. This is the original and only "RICHARED" Delicious, the Apple Supreme, and has been fully tested.

TREES GROWN. AND FOR SALE BY

\section{Highest} Market Price

\section{WASHINGTON NURSERY CO.}

\author{
TOPPENISH, WASHINGTON
}




\section{FAIRVIEW RANCH COMPANY}

C. A. Leedy, Mgr. (Sunnyslope) R.F.D. 2

WENATCHEE, WASH.

Last spring when we wanted to replant some four hundred trees where we had pulled out a wariety that was unprofitable, our attention was called to the Richared Delicious. After investigating it from very angle we decided that the Richared Delicious was the one for us to plant. Owing to the fact that it colors earlier and it therefore could be picked earlier, a greater per cent of Extra Fancy could be expected due to added color. We could probably realize more money on an earlier market. There would be fewer windfalls due to the fact that the fruit would be picked before the late fall winds.

We would have a better storage apple in case we wanted to hold until a late market. We expect to plant more Richared Delicious this spring.

\section{Very truly,

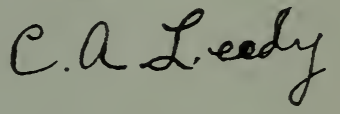

One of the largest and most up-to-date orchards in the Wenatchee Valley is owned and operated by Leedy. Bros. Mr. C. A. Leedy, the manager, is recognized as being a very able orchardist.

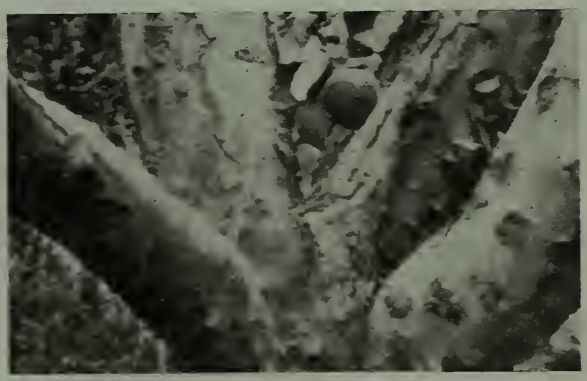

Above is a "Richared" Delicious apple growing on a small branch in the crotch of a tree. The Apple was in complete shade but it colored up perfectly; full brilliant, solid red. 


\section{The Story of "RICHARED" Delicious}

(Continued from Page 13)

\section{No Windfalls With "Richared"}

From what we have already told you, it can plainly be seen that there is no occasion for windfall "Richared" Delicious. They can all be picked with full color before they get in condition to drop off the tree.

Many an orchardist has seen two and more boxes per tree of "Windfalls" - ruined apples rotting on the ground and a year's good profits gone glimmering!

\section{More Color-Deeper Color Does It Pay?}

Here is where we lay our last and final claim for "Richared" Delicious.

We claim that under any and all general orchard conditions the "Richared" Delicious will produce on an average at least ninety per cent $(90 \%)$ Extra Fancy apples, under existing color requirements. On the other hand, common Delicious has not averaged over sixty per cent $(60 \%)$ for the past five years (figures taken from the records of local shipping organization).

\section{Yield and Returns-Common Delicious}

We give below a few actual figures on yields and packs of Delicious apples covering the last three seasons. In the Richardson orchard where the original "Richared" Delicious stands there are a few more than four hundred Delicious trees planted on a six acre tract.

In the fall of 1925, Mr. Richardson packed out 4,935 boxes of Delicious apples and received net returns on crops as follows: 1,369 boxes or $271 / 2 \%$ graded "Extra Fancy" and sold for an average net price of $\$ 2.37$, total $\$ 3,242.50$ 1602 boxes or $32 \frac{1}{2} \%$ graded "Fancy" and sold for an average net price of $\$ 1.82$. Total $2,921.16$

1,964 boxes or $40 \%$ graded "C" Grade and sold for an average net price of $\$ 1.27$. Total. 2,497.00 4,935 boxes all grades; average price $\$ 1.75$

Grand Total $\$ 8,660.66$

(Continued on Page 19) 


\section{Plant for Profit, Make Your} Orchard Pay Every Year

\section{You can do it with Richared Delicious.}

Ever since the original Delicious was placed on the market, the fruit has brought top prices, every season. When other varieties sold at a loss to the grower, the Delicious always brought a good price, that is, if the fruit was in good condition. Think what it means now to have an apple with all the good qualities of the old Delicious and in addition, have all the added color, and an apple that can be picked earlier, and one that will stay in prime condition so much longer. Those who plant now are sure to be rewarded with large profits.

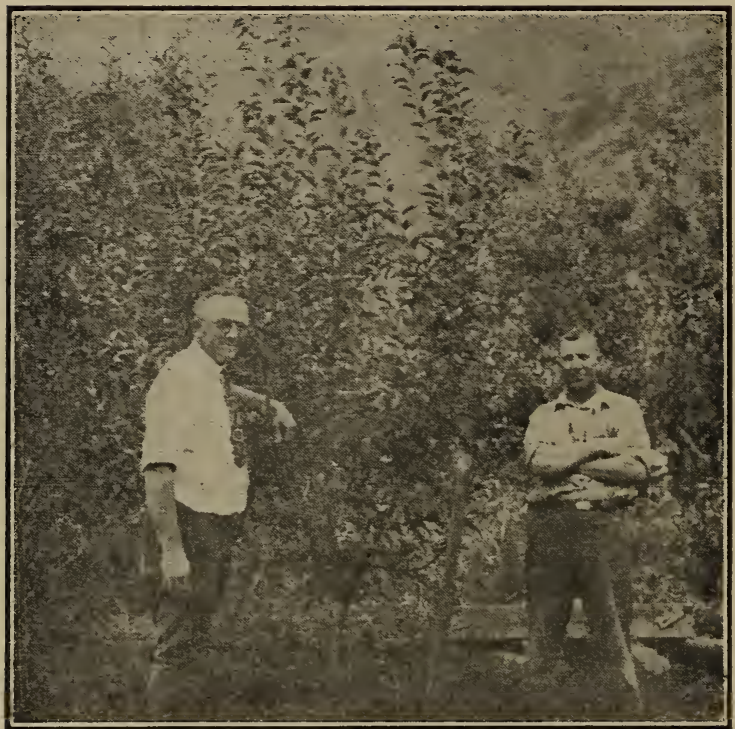

Lewis Richardson, at right (owner of original "Richared" Delicious tree), and O. T. Clawson, former president Washington State Horticultural Association, now Field Manager Northwestern Fruit Exchange, inspecting apples on third generation "Richared" Delicious tree. 


\section{Yield and Returns-" Richared" Delicious}

Suppose that his entire crop had been "Richared" Delicious.

On account of earlier market he would have received at least fifty cents per box more. By having no "Windfalls" he would have marketed at least $2 \%$ more apples (100 boxes) and his returns would have been about like this:

4532 boxes or $90 \%$ "Extra Fancy" at $\$ 2.87 \quad \$ 13,006.84$ 352 Boxes or $7 \%$ "Fancy" at $\$ 2.32 \quad 816.64$ 151 boxes or $3 \%$ "C" Grade at $\$ 1.77 \ldots \ldots$

5035 boxes all grades; average price $\$ 2.79 \ldots \ldots \ldots$

Making a net difference of $\$ 5,429.09$

More money by having "Richared" Delicious instead of common Delicious planted on a six acre tract.

In $1926 \mathrm{Mr}$. Richardson packed out 5,150 boxes, $70 \%$ Extra Fancy, 20\% Fancy, 10\% $C$ Grade, all at an average price of $\$ 1.67$ per box. Total

On the same basis, as the 1925 crop, Richared Delicious would have yielded a total_of $\$ 12,232.50$, a net difference of $\$ 3,632.00^{-}$in favor of Richared.

The 1927 crop, just packed out, amounted to 5,079 boxes, $52 \%$ Extra Fancy, 36\% Fancy, 12\% C Grade. Again "Richared" Delicious would have netted $\$ 4,864.00$ more money. Summing up, Mr. Richardson would have netted in three years a difference as follows:

Extra added profits for $1925 \quad \$ 5,429.09$

Extra added profits for $1926 \ldots \quad 3,632.00$

Extra added profits for $1927 \ldots \ldots . .564 .00$

Making a Grand Total of

$\$ 13,925.09$

For three years' crops, an average of $\$ 4,641.65$ per year.

The conditions in Mr. Richardson's orchard are not abnormal at all, and probably represent a fair average of conditions which would prevail on any six acre orchard in this valley (same age trees), given equally good care.

(Continued on Page 21) 


\section{State of Washington \\ DEPARTMENT OF AGRICULTURE \\ OLYMPIA}

I was pleased to see your exhibit of Richared Delicious apples at Wenatchee as they were the best appearing apples I have seen; also was pleased to observe the keeping qualities of the 1925 apples which you displayed as they were still crisp, which is unusual for an apple of that type.

I will likely be in the market for about seventy-five apple trees and would like to have your quotations on them.

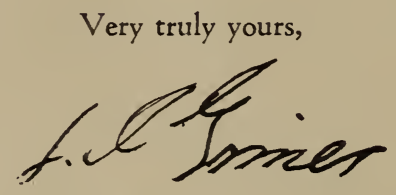

Supervisor of Horticulture, State of Washington

Mr. Griner owns an orchard and is a keen student of orchard problems.

\section{STATE COLLEGE OF WASHINGTON PULLMAN, WASHINGTON}

\section{Department of Horticulture}

I have just received five solid red Delicious apples marked Richared Delicious. These fruits are Delicious apples in all respects except color. They are solid red and show no indications of stripe or blotch.

From the reports I have been able to gather, this Richared Delicious tree produces solid red apples only, and is a Delicious in every other characteristic. It seems to me that such a tree would be of superior value compared to the old standard striped Delicious. There is no reason to anticipate its changing its character when propagated and reproduced in new or young trees.

Yours very truly,

\section{oincuoure}

\section{Head, Department Horticulture, Washington State College.}

Professor Morris has studied orchards in the Northwest for years. His word carries a great deal of weight with orchard planters in this district. 


\section{The Story of "RICHARED" Delicious \\ (Continued from Page 19)}

\section{Repeat Orders}

Again we wish to call your attention to the testimonials on preceding pages. Note the significance, when men like A. Z. Wells, C. A. Leedy and Geo. McAulay, all orchard men of experience, men who market apples on a large scale, each planted "Richared" Delicious trees this year and each will plant more next season. They realize what a wonderful apple we have discovered in the Richared Delicious.

\section{Enormous Demand}

On acocunt of superior keping qualities which will greatly lengthen the period of distribution-and place apples in consumers' hands in much better condition, the demand for "Richared" Delicious is sure to be enormous.

We believe that you will agree with us that the above facts and figures conclusively prove that in "Richared" Delicious we have discovered the greatest apple in the world.

\section{A Few Reasons Why You Should Plant "Richared" Delicious}

Earlier picking.

Earlier marketing.

No Windfalls.

More and better color.

(Practically every apple on the tree Extra Fancy color.)

Much better prices.

More profits.

Satisfied customers, both dealer and consumer.

Better keeping qualities-can be kept for late Spring Market, in years when earlier markets may be "Glutted."

At least two weeks more time after harvest in which to do other work, or take the extra money to take a real vacation. 


\section{All Tests Have Been Made}

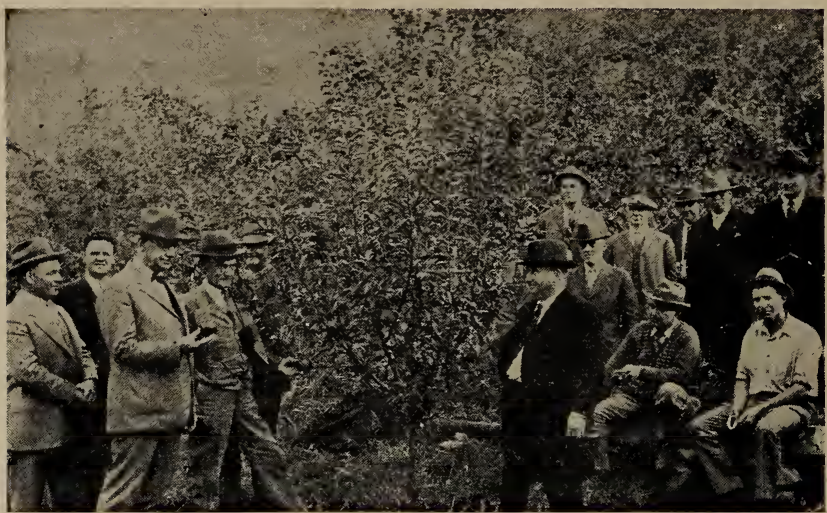

Prominent Fruit Men Inspecting the Apples on a Third Generation "Richared" Delicious Tree.

On invitation, orchardists, shippers, government horticulturists, bankers, merchants, representatives of the press, gathered at the orchard of Lewis Richardson (owner of the original tree), in September, 1926, where they were shown not only the original tree, with its load of about 20 bushels of blood red fruit, but also some of the young trees, which were also bearing apples identical with those on the parent tree.

\section{Extract from a Letter Received}

\section{from J. M. Gwin \& Co.}

Seattle, Washington,

October 8, 1927.

Having received the actual information relative to the Richared Delicious, we ourselves feel these are the most wonderful samples we have ever seen and it is certainly wonderful how they hold up. They are full of juice and life, too. (Samples from cold storage 14 months old.)

J. D. HORTON, of J. M. Gwin \& Co., Seattle, Washington. 


\section{"Richared" Reproduces True to}

Type

\section{WENATCHEE PRODUCE CO.. INC.}

Wenatchee, Wash., Oct. 22, 1927.

I was indeed surprised when I first saw the original "Richared" Delicious tree at the Richardson Orchard during the early fall of 1926, which at that time was loaded down with deep red apples, while the apples on the other Delicious trees in the same orchard were still green.

I also saw the young trees propagated from the parent tree and they also were bearing apples of identical type.

Yours truly,

WENATCHEE PRODUCE CO.

$$
\text { By }
$$

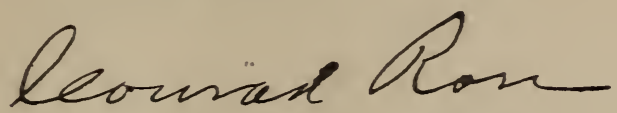

President.

Every apple buyer has heard of the famous "Rose Brand" put out by the Wenatchee Produce Company.

\section{CHELAN COUNTY}

$$
\text { and }
$$

\section{STATE COLLEGE OF WASHINGTON}

Co-operating

I have been keenly interested in the Richared Delicious that you are now propagating. Having seen the apple growing on the original tree and also on young trees of the second generation it seems evident that it is a variety with excellent possibilities for a leading commercial apple. After having seen and tasted the apples that have carried through one storage season and practically through another there seems to be little doubt as to its superior qualities.

As the Delicious apple has been a great asset to the fruit growers of the Northwest, I believe this variety adds much to the permanency of the Delicious varietv. The Richared Delicious will not have to build up a demand on the markets of the world but will help fill a place that is already being demanded by the trade. Yours truly,

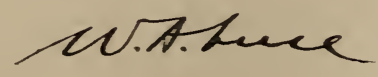

Horticultural Investigator.

Some of the most practical experiments in Horticulture in the Wenatchee Valley have been brought to a successful conclusion by Mr. Luce. 


\title{
Should Commend Itself to the Trade at Sight
}

WENATCHEE DISTRICT CO-OPERATIVE ASSOCIATION

\section{Jim Hill \& JimD andy APPLES}

\author{
GENERAL OFFICES \\ WENATCHEE, WASHINGTON
}

October 12, 1927.

I am greatly interested in your new apple, the "Richared" Delicious and feel sure that it has wonderful possibilities. On account of its brilliant deep red color, it should commend itself to the trade at sight. Also the fact that it can be picked and shipped while hard ripe is very important. Many a grower has shipped out Delicious which to all appearances were prime, only to have them reach the market in an over-ripe condition and as a result has received very small returns for otherwise Extra Fancy apples. Many a dealer has likewise bought such apples only to suffer loss. As I see it, you can entirely overcome this objectionable feature with the Richared Delicious, as tests have proven that it is an excellent keeper if picked at the proper time. I can see no reason why anyone would plant common Delicious if he could procure the Richared Delicious. It looks like a sure-fire winner to me.

Yours very truly,

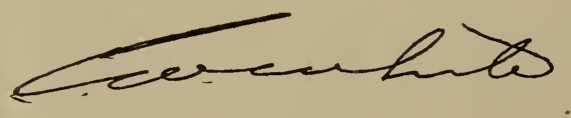

General Manager.

"Jim Hill" Apples is a household term. The Wenatchee District Co-Operative Association, of which Mr. White is Manager, markets a large portion of Wenatchee Valley's large apple crop. 


\section{Proof of the Excellent Keeping Qualities of the "Richared" Delicious}

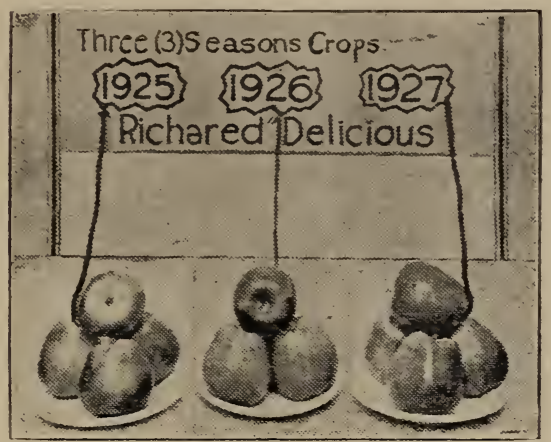

The above picture is taken from a photograph of three plates of "Richared" Delicious apples exhibited at Washington State Fair, Yakima, Washington, September 16, 1927. Orchardists who examined the 1925 and 1926 apples were astonished to find them still firm and crisp. The Nursery Company also put on a similar exhibit at the National Fruit Show held at Kansas City, Missouri, Nov. 28-30, 1927. These apples on the three plates were seen and handled by hundreds of orchardists, many of whom afterward placed orders for trees. These apples were kept in Ordinary Cold Storage. THINK OF IT! Delicious Apples kept for over two years and still in good condition.

SEE TESTIMONIAL ON NEXT PAGE:

EXTRACTS FROM A LETTER FROM GWIN, WHITE \& PRINCE, WENATCHEE, WASH., TO THEIR MAIN OFFICE LOCATED AT CHICAGO, ILL.

October 2, 1926.

Mr. Richardson has grown these Richared Delicious for several years so there is no question about the variety being permanent. $\mathrm{He}$ is not yet in a position to offer these apples in carloads, but will be some of these days, so we want you to become acquainted with this fruit and show samples to your friends on the Chicago market, who are Delicious hounds.

These samples have been in this hot office several days and our guess is that they will reach you in good condition. Wonderful, isn't it? Please write us fully after vou have examined and exhibited these samples.

GWIN, WHITE \& PRINCE, By W. F. GwIN, Wenatchee, Wash. 


\section{Storage of Common Delicious and "Richared" Delicious Compared}

\section{COLUMBIA ICE \& C COLD STORAGE CO. ICE PRE-COOLING FREEZING FORWARDING}

Wenatchee, Wash., October 13, 1927.

I have watched with a great deal of interest your experiments in keeping the Richared Delicious in cold storage. The records of our company, The Columbia Ice \& Cold Storage Co., show that in the fall of 1925 you placed several boxes of Richared Delicious in our keeping and I have seen with my own eyes these same boxes opened up two years later and the fruit came out in prime condition; still hard, firm, crisp, juicy and full of flavor.

I have also seen these Richared Delicious apples taken out of storage after being kept for over a year, and three weeks later they were still in prime condition.

This has proved to me beyond question that in the "Richared" Delicious you have an apple which we can put in storage and feel confident that it can be placed on the late spring or early summer market in good condition.

All cold storage plants have had trouble in trying to keep in storage common Delicious, as almost invariably the apples are not picked, on account of lack of color, until ripe, and then they soon break down. Your "Richared" Delicious, on the other hand, colors before it is ripe and it will surely make a wonderful storage apple.

Yours truly,

Columbia Ice \& Cold Storage Co.

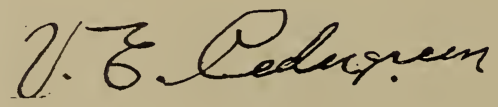

Manager.

Please read the last two paragraphs again. Mr. Cedergreen is an authority. His company ices all the cars of fruit (thousands of them) which are sent out iced from the Wenatchee Valley every season. Their Cold Storage Plant equipment is probably not excelled in the world. 


\section{Will Entirely Replace Planting of}

\section{Common Delicious}

\section{R. EDWARD TRUMBLE}

Consulting Horticulturist

I have seen and observed your new strain of Delicious, the "Richared," both on the original parent tree and also the apples on the young trees, and in my opinion you have the most beautiful apple in the world. It is certainly marvelous to see these, full blood red color in August, while Delicious on adjoining trees are still green. T'is added color with advantages of earlier picking, earlier marketing, firmer apples, more extra fancies, no loss from "Windfalls," and better keeping qualities, convinces me that in the "Richared" Delicious you have an apple worth millions of dollars to the apple industry of the world.

I have seen and tasted your "Richared" Delicious which the records at the cold storage plant showed were kept in cold storage for three (3) seasons-apples picked in 1925 and still firm, crisp and juicy in September, 1927, two years later.

I have no hesitancy in stating that in my opinion the "Richared" Delicious will entirely replace plantings of common Delicious and that it is a better apple from every standpoint.

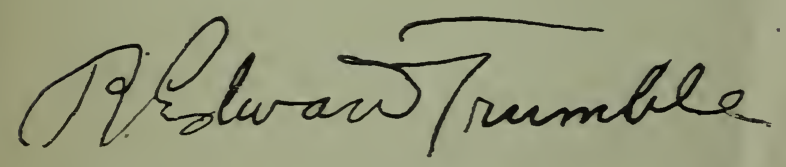

Consulting Horticulturist,

Wenatchee, Washington.

Mr. Trumble is a practical Horticulturist. He has resided in Wenatchee for the past twenty years and has been closely identified with orchards and orchard prob. lens. 


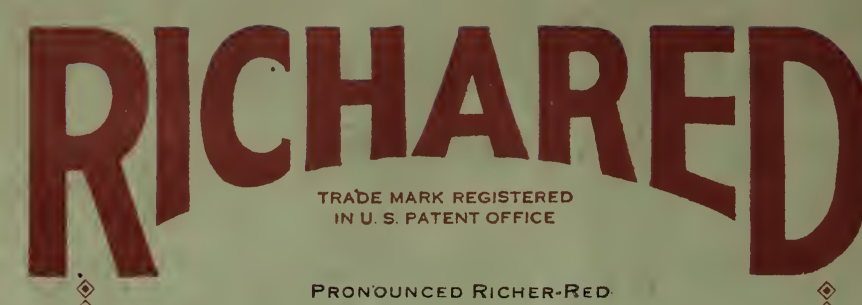

PRONOUNCED RICHER-RED

\section{THE \\ DELICIOUS \\ SUPREME}

$\infty$

Indorsed by

Leading Fruit Growers

Horticultural Experts

Shippers and Dealers

Everywhere

no

Washington

Nursery Co.

Toppenish, Washington 